\title{
THE OPINION OF VISITORS ON THE TOURISTIC ATTRACTIONS AND SERVICES OF THE ESTERHAZY CASTLE OF FERTŐD
}

\author{
László A. Bodrogai ${ }^{1}$, Orsolya Szigeti ${ }^{2}$ \\ ${ }^{1}$ Kaposvár University, Faculty of Economic Science, Doctoral School in Management and Organizational Sciences \\ Guba Sándor street 40., H-7400 Kaposvár \\ bodrogailaszlo@gmail.com \\ ${ }^{2}$ Kaposvár University, Faculty of Economic Science, Institute of Marketing and Management \\ Guba Sándor street 40., H-7400 Kaposvár \\ szigeti.orsolya@ke.hu
}

\begin{abstract}
The lately renovated Esterhazy Palace is one of Europe's biggest Baroque palaces. This paper examines the visitors' opinion of this worldwide famous palace. This survey-based study was carried out in 2016/2017. The sample was of 800 people, using paper-based questionnaire. It emerged from the study that the visitors needed to be separated analyzed differently under and above 18 years of age, because the push and pull factors vary significantly. Other words, the adult visitors (persons, families) decided themselves to go and see or not, but the young people were influenced by their teachers. Other important lessons of the study was that the visiting process does not end with the viewing of rooms and tools, but the different souvenirs and providing further information, and services are also part of it. This is evidenced by the fact that the worst rating was given by the related service. Organizing and ensuring this is an important task of the management of the palace.
\end{abstract}

Keywords: Cultural Heritage Tourism, Management, Esterházy Palace Fertöd, Visitor Survey.

(JEL Classification: M3. O18, Z32)

\section{INTRODUCTION}

The lately renovated Esterhazy Palace of Fertőd is one of the biggest Baroque-Rococo palaces of Europe. The objective of this research was to get to know the visitors' opinion about the cultural attractions and services of the Esterházy Palace. This paper examines the visitors' opinion of this worldwide famous palace.

The palaces have a double function embedded in the touristic system of the destination, following the logic of competence marketing. They are a special part of the offer and have a close connection to communication activity. With a function restoring and expanding renovation they can become unique attractions, which are by themselves capable of attracting tourists to the region. In addition, because of their special infrastructures, they can become service locations, such as accommodation, catering unit, event location or part of the program offer. Beside their autonomous presence they are the foundation of thematic products and offer packages in the regional network (KULCSÁR et al., 2017). In other words, a touristic destination is not "left hanging in the air", but lives with its environment and region, it's not separated, but an organic part of the regional processes. It is very important for the tourism management that the Esterhazy Palace as a touristic product be seen in unit with the touristic processes of the region (BODROGAI et al, 2016). Beside the reinforcing of local identity, it has a big influence in communication marketing, that is they promote the notoriety and reputation of the region. 


\section{MATERIALS AND METHODS}

\section{Materials}

Cultural tourism has been typified in many dimensions in the secondary literature, CROUCH (2009) for example distinguished the nature of cultural tourism towards the „high or intellectual” cultural attractions from the so called "mass or popular" cultural tourism. The numerous approaches generated a widely spread discussion about tourism and the marketing connected to it. The perhaps strongest stream of criticism has unfolded between the so called classical and postmodern points of view. According to the postmodern position, the previous stream of the cultural tourism produced the so called „staring at it, but not seeing it" phenomenon, in other words the „Kodakization” of cultural tourism, which concentrates on the preservation of cultural values on photographs. The critics of this theory mention, in relation to the postmodern approach, the relativization of values, during which each person decides for themselves what they think of as important, interesting and the reasons why. The postmodern cultural tourism exceeds the so-called theories of representational tourism, edging towards everyday life (WEAVER, 2011). STYLIANOULAMBERT (2011) emphasizes this positive trait, according to which the postmodern trends prefer the subjective approach and methods, and so the subjective experiencing (STYLIANOU-LAMBERT, 2011). The heritage tourism is closer to the classical point of view, which gives a special importance to the identity reinforcing effect of touristic experience. MILLAR (1989) defined the functions of heritage tourism as following: touristic attractions and representations, formal and informal education, reinforcing the collective and national identity, economic success (MILLAR, 1989). According to his opinion, in case of the tourism in sync with the classical point of view all functions could come true more effectively than following the logic of the postmodern tendencies.

One of the central dilemmas of the cultural heritage tourism is the conflict between „Art for art” and „Art for business” (SETYAGUNG et al., 2013). This is probably the most important, but also the most difficult task for the heritage management. SETYAGUNG and his coworkers offer a possible answer to this opposition, to the lifting of artistic and business-like approach with the model based on the so called „Triple Helix” paradigm (Figure 1) (SETYAGUNG et al., 2013).

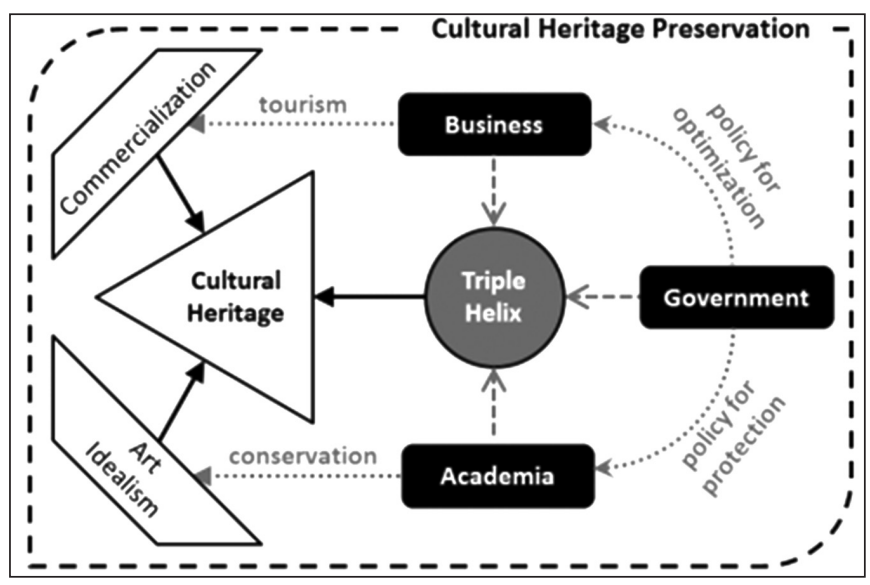

Figure 1: The „Triple-Helix" model and the commercial and artistic activity in cultural heritage protection

Source: SETYAGUNG et al., 2013
The disintegration of balance forecasts damage in the cultural or nature conservation area of heritage protection (for example, if the dominance of the business approach is strong and politics does not restrict it) (FAGANEL, TRNAVCEVIC, 2012). At the same time the model shows us the possible damaging effects, when the cultural heritage closes up in an ivory tower from the surrounding economic, social and ecological system.

The heritage tourism management can choose between three theorical models of the value orientation which will characterize its activity (DELLA CORTE et al., 2009). The traditional model concentrates on the preservation of heritage values and its primarily tasks are the diffusion of the knowledge related to it. The consumer-oriented model focuses on the social status and desires of the consumer and concentrates accordingly on the technological aspects, deemphasizing the historical, archeological and cultural aspects. In the center of the third model is the value assimilation, during which the visitor takes an active part in the process. According to the authors (and the social trends) this third model will become more and more emphasized in the future in area of heritage management. The economical profit of cultural heritage is not equivalent to the produced financial profits; the social profit of cultural heritage can exceed the financial profit by many times (RUIJGROK, 2006).

The characteristics of the visitors of cultural heritage values (e.g. motivation, needs and expectations, previous experiences, qualification, price sensitivity) define fundamentally the possible direction of the development and management of values. The secondary literature has many existing typifications, which put mostly the motivation at the center of study (PETR, 2015). SHENG and CHEN (2012), based on the completed factor analysis, distinguish between visitors 1) who desire curiosities and light entertainment, 2) who desire cultural entertainment, 3) who want to gain reinforcement in the cultural aspect and historical identity of their personalities, and 4) those who want to reinforce their dreams and visions (SHENG, CHEN, 2012). NIEMCZYK (2013), examining the consciousness of visitors, hypothesizes five basic visitor types: 1) conscious visitor, who chooses to visit the institution based on a rational decision, 2) the visitor who disposes of relative (e.g. artistic) abilities, 3) the sightseer, who visits monuments, 4) the accidentally entering, and 5) the occasional, casual visitor (NIEMCZYK, 2013). According to NIEMCZYK (2013), the group of visitors can differ significantly depending on how much importance they give to culture in their choices, i.e. in what measure the cultural values motivate their choice as visitors. On the other side, how open they are to the reception of cultural experiences, i.e. in what measure they experience the values channeled by the attraction in question. The segmentation based on this of channeled values and visitors defines in the optimal case the activity of the management. This activity has to be based on a marketing conception that counts consciously with the different value systems and attitudes of visitor groups and, in the case of the Esterhazy Palace, with the multilayer approach to the touristic destination. The conceptional model of the 
marketing activity of the Esterhazy Palace is shown in Figure 2. The model counts with two fundamental visitor types.

The onefold visitor has curiosity mostly for the palace and the tangible elements of the connected cultural heritage values (e.g. buildings, furniture etc.). His curiosity is satisfied by the visualization of this in form of an attraction. The onefold visitor who during the guided tour takes a lot of photographs when possible but will probably not return.

The other type is more profoundly interested in the cultural attraction. His positive attitude and emotional connectional is paired with trust and commitment. This returning visitor has stronger cultural roots and interest, someone who desires a more intensive experience and is a regular consumer of the higher cultural attractions.

Figure 2: The conceptual model of the marketing activities of the Palace

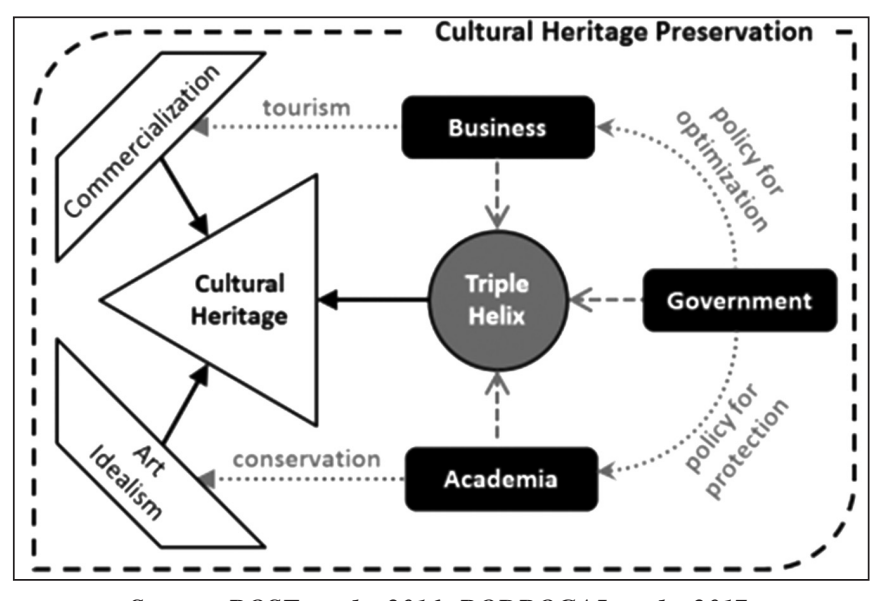

Source: ROSE et al., 2016; BODROGAI et al., 2017.

In practice the classification of tourists based on the model above is not an easy task.

\section{Methods}

The paper sums up the results of a quantitative primer study. The survey about their impressions and opinions was filled out by 800 visitors of the palace in the years 2016 and 2017 before they lef. The survey was processed by IBM SPSS program. The visitors can be divided in two fundamental groups: on one side the young people (students of elementary, middle and high school) who come on organized trips to the Palace as complementary part of the school program, on the other side the adult visitors and families who come by car or bus from the different parts of the country or are staying in the vicinity, as well as those who stop on their way to Austria to visit the Palace.

The essence of the different motivations of the two groups will be described in the following. From the point of view of the marketing research we separated the young people (maximum 18 years of age) from the adult visitors, because we supposed, rightly in most cases, that most of these young people was group visitors, i.e. school students of different levels. In these cases, the goal and the motivation of the visit depends greatly on the interests and orientation of the accompanying teachers and on the opinion of the school board. From a different approach to the topic, the students get a ready-made orientation, the marketing activity of the palace does not (or in very little measure) affect them directly. Of similar experience report PESARO and RUBEGNI (2010). They also raised the question of the different motivation between younger and older people.

From a methodological point of view, it was important to form two groups by the analysis of the visitor surveys, one of the adults and the other of the young people (students).

\section{RESULTS AND DISCUSSION}

About the social composition of visitors and the opinion about the programs of the palace

In Europe one of the most important motivations of the touristic mobility is culture. Although the participants of cultural tourism have heterogenous characteristics, we can say that in general these cultural tourists are relatively high educated, have an income exceeding the average, and the proportion of women is a little over the average. The data recovered from a study about the knowledge and attitude of the Hungarian population about cultural tourism (MAGYAR TURIZMUS ZRT., 2008) confirms this correlation. According to the results of the MAGYAR TURIZMUS ZRT. (2008), those who have had a higher education and belong to the group of people with higher income are the ones mostly interested in cultural tourism.

In terms of age, it is possible to find both older and younger generations, but there is a difference in their interests: the older people are more interested in the cultural heritage attractions, while the younger ones are more attracted by the events and popular culture. LIN (2006) gets to similar conclusions: he experienced in the greatest proportion of lack of interest for cultural museums among people with lower education and income. What overlaps with other European experiences are the expectations of these social groups from the museums: spending of free time and meeting with popular culture.

\section{Young people in the Esterhazy Palace}

The average age of young people is 12.5 years, which justifies the decision to separate the sample in two groups. It is visible that this is the age of students in middle school. The proportion of older, but still young visitors was $25.3 \%$.

$21.6 \%$ of young visitors have already visited the palace, but for the majority of them it was the first time. The major source of information for these young people is supposed to be educational institution. Other than the schools, according to the answers mostly the Internet $(54.1 \%)$ and the masscommunication devices were nominated as source $(31.9 \%)$. In a proportion that is worth mentioning are friends and acquaintances as source of information (15.0\%).

$93.0 \%$ of the young people participated in a guided tour. In this a significant circumstance was the fact that they belonged 
to a visitor group (school group), where the participation on a guided tour was mandatory.

The satisfaction of visitors was measured by asking about the opinions according to a few points of view. Table 1 shows the satisfaction data on a five-point Likert scale. 1 means "I am not satisfied at all" and 5 means "I am totally satisfied".

Table 1: Satisfaction levels among young visitors

\begin{tabular}{|l|c|c|c|c|c|c|c|}
\hline \multirow{2}{*}{ Point of view } & \multicolumn{5}{|c|}{ Satisfaction level, \% } & \multirow{2}{*}{ Average } & $\begin{array}{c}\text { St. } \\
\text { dev. }\end{array}$ \\
\cline { 2 - 7 }$(1)$ & $(2)$ & $(3)$ & $(4)$ & $(5)$ & & 1.07 \\
\hline $\begin{array}{l}\text { Completion of } \\
\text { expectation about } \\
\text { the Palace }\end{array}$ & 4.6 & 5.6 & 16.8 & 37.5 & 35.5 & 3.94 & 1.03 \\
\hline $\begin{array}{l}\text { Impression about the } \\
\text { Palace complex }\end{array}$ & 3.1 & 5.6 & 22.7 & 33.7 & 34.9 & 3.92 & 1.03 \\
\hline $\begin{array}{l}\text { Impression about the } \\
\text { coworkers }\end{array}$ & 4.3 & 4.1 & 19.7 & 39.9 & 32.0 & 3.91 & 1.03 \\
\hline Guided tour & 5.8 & 4.5 & 17.4 & 42.4 & 29.8 & 3.88 & 1.07 \\
\hline $\begin{array}{l}\text { Offer of the souve- } \\
\text { nir shop }\end{array}$ & 8.0 & 15.8 & 26.4 & 24.5 & 25.3 & 3.43 & 1.24 \\
\hline
\end{tabular}

The young visitors were best satisfied with the correspondence to their expectations. The measured differences between the averages of satisfaction levels were minimal in most cases. They were mostly critical about the offer of the souvenir shops and the guided tour. By the judging of the souvenir shop we experienced the biggest dispersion of opinions, i.e. the least unitary judgment. It can be observed that the average of satisfaction level never reached the 4.0 threshold. About one third of young visitors can be characterized by maximum satisfaction level.

Some things should be changed according to the opinion of young visitors, to optimize the level of satisfaction. Most mentioned were the following:

- Expanding the offer of the souvenir shop

- The prices of the souvenir shop are high

- Show more rooms

- Possibility to get closer to the objects

- Possibility of Baroque photoshoot

- Lower the load/burden of the lady in the cafeteria

- Benches in the garden

- Child-friendly guided tours

- Free Wi-Fi

- Stops for rest on guided tours

The management of the Esterhazy Palace must take into consideration the opinions about satisfaction, because the impressions in the younger visitors can take effect on the visiting of later generations, but also on the people in their social nets. Despite the critical opinions $91.2 \%$ of the younger people would suggest the palace to their friends and acquaintances. This number is very high, even if these intentions get lower later. Most young people would like to visit further attractions of the palace complex, for example the Orange House, the Marionette Theater, the Water Tower, the Rose Garden, the Les Forest and the Haydn Chamber.

\section{Adult visitors in the Esterhazy Palace}

In the following we will be presenting the opinions of the adult visitors. We have already explained the division of the visitors into two groups. The distribution of visitors by sex is close. The proportion of male visitors is $50.5 \%$, that of women is $49.5 \%$. For more than half the palace was not a novelty $(51.9 \%)$. This number suggests that visitors can be divided in different groups, as mentioned above by the typification of visitors. Who has visited the castle multiple times is probably more profoundly interested in cultural values.

We asked adult visitors on the questionnaire what kind of sources heard about Palace from. $45.8 \%$ of adult visitors mentioned that they heard about the Esterhazy Palace via Internet. This information device got the most mentions. Now look at the proportions in which the information sources got mentions (one responder could nominate more sources) (Table 2).

Table 2: Information sources about Esterhazy Palace, \%

\begin{tabular}{|l|l|}
\hline Categories of answer & Distribution of answers \\
\hline Internet & 45.8 \\
\hline Mass communication & 43.2 \\
\hline $\begin{array}{l}\text { Associations of Hungarian Touristic Destination } \\
\text { Management }\end{array}$ & 20.8 \\
\hline Friends, acquaintances & 17.3 \\
\hline Tour-inform & 8.6 \\
\hline Event organizers & 7.0 \\
\hline Facebook & 6.3 \\
\hline Travel agency & 5.6 \\
\hline Accommodation & 5.6 \\
\hline Advertisements & 3.3 \\
\hline
\end{tabular}

This sequence is very instructive. It shows that the internet and the mass communication are very efficient in spreading the information. This kind of active demand, where the palace gives information (internet, mass communication), but plays an otherwise passive role (pull) is widely accepted and practiced marketing approach (BODROGAI et al., 2017). Contrary to when the palace actively puts pressure on spreading the information and increasing the number of visitors („pull”) looks less efficient (event organizer and different agencies). The right conclusion is naturally not using the latter, but to make an effort to increase their efficiency. In case of the Esterhazy Palace the „pull” factors will always have a more significant role to increase the number of visitors. $94.1 \%$ of the adult visitors have participated in a guided tour, and this circumstance could also increase the possibility of application of the pressure marketing.

The analysis of the satisfaction level of adult visitors has been carried out with the above described methodology. The dimensions of satisfaction were the same. The results can be seen in Table 3 . 
Table 3: Satisfaction levels among older visitors

\begin{tabular}{|l|c|c|c|c|c|c|c|}
\hline \multirow{2}{*}{ Point of view } & \multicolumn{5}{|c|}{ Satisfaction level, \% } & \multirow{2}{*}{ Average } & $\begin{array}{c}\text { St. } \\
\text { dev. }\end{array}$ \\
\cline { 2 - 8 } & $(1)$ & $(2)$ & $(3)$ & $(4)$ & $(5)$ & 0.99 \\
\hline $\begin{array}{l}\text { Impression about the } \\
\text { coworkers }\end{array}$ & 4.6 & 3.4 & 15.4 & 46.7 & 29.9 & 3.94 & 0.92 \\
\hline Guided tour & 4.3 & 5.5 & 14.5 & 45.5 & 30.2 & 3.92 & 1.02 \\
\hline $\begin{array}{l}\text { Impression about the } \\
\text { Palace complex }\end{array}$ & 4.3 & 5.1 & 20.2 & 43.6 & 26.7 & 3.83 & 1.02 \\
\hline $\begin{array}{l}\text { Completion of } \\
\text { expectation about } \\
\text { the Palace }\end{array}$ & 4.6 & 5.0 & 19.9 & 45.5 & 24.9 & 3.81 & 1.02 \\
\hline $\begin{array}{l}\text { Offer of the souve- } \\
\text { nir shop }\end{array}$ & 7.0 & 13.8 & 31.6 & 30.7 & 16.9 & 3.37 & 1.12 \\
\hline
\end{tabular}

In the case of the older visitors the souvenir shop got the most critical evaluation, but here the opinions were the least unitary. Compared to the other points of view and to the valuation of the younger visitors their impressions about the Palace are more negative. The opinions were the most united by the judging of the coworkers, and also the most positive. The average of the valuations is in every case under the 4.0 threshold.

The management must also pay attention to the fact that the souvenir shop got the worst valuation in both visitor groups. The souvenir shop, as described by FIGUEIREDO et al. (2015), is not only a market institution, but contributes to the reinforcement of identity and to the spreading of the perception of sustainability. Because of this, the results of this study make a more detailed exploration and measures needed.

The visitors, not only concerning the souvenir shop, suggest the following changes for the management of the Palace:

- More and better directional signs

- Solve the parking problems/issues

- Keep to the preannounced times of the guided tours

- Expanding the offer of the souvenir shop

- Politer attitude of the staff

- The staff should not talk about personal problems in front of visitors

In opposition to the relatively low-key valuations $92.8 \%$ of the visitors would suggest visiting the Palace. The majority (67.5\%) would also visit the attractions not present in the program (Rose Garden, Marionett Theater, Orange House, Water Tower).

\section{SUMMARY}

In summary, we can highlight that identifying the visitor groups of the cultural destination and the realization of the segmented marketing work is very important. Much of the literature agree with this differentiated marketing approach and the re-evaluation of the work of the management according to this. Similarly, the management must put the approach at the center, according to which the cultural touristic institution needs to be positioned in a unified view with its environment. A significant cultural institution and the network of touristic, service, etc. relations of the region could free up serious synergy for the development of the region too.

\section{REFERENCES}

1. Bodrogai L. A., Vizi I. G., Kulcsár L, (2017) Az örökségturizmus résztvevői és a kulturális örökség látogatóinak információ forrásai a fertődi Esterházy Kastély példáján. Tér - Gazdaság - Ember 5 (1) 79-94.

2. Bodrogai, L. A., Kulcsár L., Vizi I. G. (2016) A helyreállított fertődi Esterházy Kastély térségi szerepéről alkotott vélemények a gazdasági szereplők körében. Gazdaság és Társadalom 8 (1) 59-75.

3. Crouch, D. (2009): The Diverse Dynamics of Cultural Studies and Tourism. In: Jamal, T., Robinson, M. (eds): The Sage Handbook of Tourism Studies 82-97.

4. Della Corte, V., Savastano, I., Storlazzi, A. (2009): Service innovation in management and valorization of cultural heritages. International Journal of Quality and Service Sciences 1 (3) 225-240.

5. Faganel, A., Trnavčevič, A. (2012): Sustainable natural and cultural heritage tourism in protected areas. Case study 589-600. ANNALES Ser. hist. sociol. 22·2.

6. Figueiredo Albuquerque, M. H., Bravo Lima Delgado, M. J. (2015): Sustainable museographies - The museum shops. Procedia Manufacturing (3) 6414-6420.

7. Kulcsár L., Bodrogai L. A., Vizi I. G. (2017) Tourism development and cultural heritage: The stakeholders' opinion on the role of restored Esterházy Palace in Western Hungary. Economic Though and Practice (2) 813-827.

8. Lin, Y-N. (2006): Leisure - A function of museums? The Taiwan perspective. Museum Management and Curatorship 21 (4) 302-316.

9. Magyar Turizmus Zrt. Kutatási Csoport (2008): A magyar lakosság kulturális turizmussal kapcsolatos ismeretei, attitűdjei és utazási szokása. Turizmus Bulletin 12 (3) 2-19.

10. Millar, S. (1989): Heritage management for heritage tourism. Tourism management 10 (1) 9-14.

11. Niemczyk, A. (2013): Cultural Tourists: "An attempt to classify them. Tourism Management Perspectives (5) 24-30.

12. Pesaro, G., Rubegni, E. (2010): The Cultural District as a driver of local development: design and implementation experiences in the Lombardy Region. SA Research Network Sociology of Culture Midterm Conference: Culture and the Making of Worlds DIAP - Politecnico di Milano.

13. Petr, C. (2015): How heritage site tourists may become monument visitors. Tourism Management (51) 247-262.

14. Rose, G. M., Merchant, A., Orth, U. R., Horstmann F. (2016): Emphasizing brand heritage: Does it work? And how? Journal of Business Research 69 (2) 936-943.

15. Ruijgrok, E. C. M. (2006): The three economic values of cultural heritage: a case study in the Netherlands. Journal of Cultural Heritage (7) 206-213.

16. Setyagung, E. H, Hani, U., Azzadina, I., Sianipar, C. P. M., Ishii, T. (2013): Preserving Cultural Heritage: The Harmony between Art Idealism. In: Setyagung et al.: Commercialization, and Triple-Helix Collaboration. American Journal of Tourism Management 2 (1) 22-28

17. Sheng, C. W., Chen, M. C. (2012): A study of experience expectations of museum visitors. Tourism Management (33) 5360. 
18. Stylianou-Lambert, T. (2011): Gazing from home: cultural tourism and art museums. Annals of Tourism Research 38 (2) 403-421.

19. Weaver, D. B. (2011): Contemporary tourism heritage as heritage tourism. Evidence from Las Vegas and Gold Coast. Annals of Tourism Research 38 (1) 249-267. 